Asymmet ri c reduct i on of al i phat i c ket ones and acyl si I anes using chi $r$ al ant i - pent ane-2,4 di ol and a cat al yt i c amount of 2,4 di ni trobenzenesul foni $c$ aci $d$

\begin{tabular}{|l|l|}
\hline 著者 & $\begin{array}{l}\text { Nat suo Juni chi, Hat t or i Yu, Hashi zune Mo, } \\
\text { I shi bashi H royuki }\end{array}$ \\
\hline $\begin{array}{l}\text { j our nal or } \\
\text { publ i cat i on ti l l e }\end{array}$ & Tet r ahedr on \\
\hline vol une & 66 \\
\hline number & 32 \\
\hline page r ange & $6062-6069$ \\
\hline year & $2010-01-01$ \\
\hline URL & ht t p: //hdl . handl e. net /2297/25207 \\
\hline
\end{tabular}




\section{Graphical Abstract}

To create your abstract, type over the instructions in the template box below.

Fonts or abstract dimensions should not be changed or altered.

\begin{tabular}{|c|c|}
\hline \multicolumn{2}{|l|}{$\begin{array}{l}\text { Asymmetric reduction of aliphatic ketones } \\
\text { and acyl silanes using chiral anti-pentane- } \\
\text { 2,4-diol and a catalytic amount of } 2,4- \\
\text { dinitrobenzenesulfonic acid }\end{array}$} \\
\hline \multicolumn{2}{|c|}{$\begin{array}{l}\text { Jun-ichi Matsuo,* Yu Hattori, Mio Hashizume and Hiroyuki Ishibashi } \\
\text { School of Pharmaceutical Sciences, Institute of Medical, Pharmaceutical and Health Sciences, Kanazawa } \\
\text { University, Kakuma-machi, Kanazawa 920-1192, Japan }\end{array}$} \\
\hline 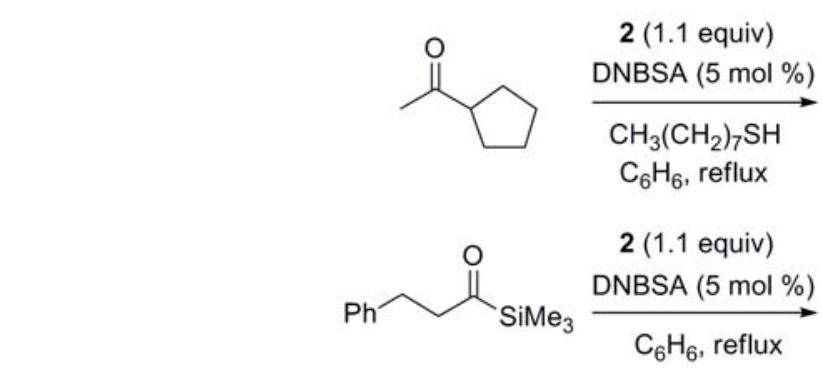 & \begin{tabular}{l|l}
$\mathrm{SiMe}_{3}$ & $\mathrm{O}_{2} \mathrm{~N}$ \\
$\mathrm{\%} \mathrm{ee}$
\end{tabular} \\
\hline
\end{tabular}




\title{
Asymmetric reduction of aliphatic ketones and acyl silanes using chiral anti-pentane-2,4-diol and a catalytic amount of 2,4- dinitrobenzenesulfonic acid
}

\author{
Jun-ichi Matsuo, * Yu Hattori, Mio Hashizume and Hiroyuki Ishibashi \\ School of Pharmaceutical Sciences, Institute of Medical, Pharmaceutical and Health Sciences, Kanazawa University, Kakuma-machi, \\ Kanazawa 920-1192, Japan
}

\begin{abstract}
Aliphatic ketones were reduced to the corresponding secondary alcohols by using anti-1,3-diol and a catalytic amount of 2,4dinitrobenzenesulfonic acid (DNBSA) in benzene at reflux. Addition of 1-octanethiol in that media improved the efficiency of the reduction. Asymmetric reduction of aliphatic ketones was performed by using chiral anti-pentane-2,4-diol, and highly asymmetric induction (up to $>99 \%$ ee) was observed in the reduction of tert-alkyl ketones. Asymmetric reduction of acyl silanes using chiral antipentane-2,4-diol and DNBSA proceeded efficiently in the absence of octanethiol and the corresponding $\alpha$-silyl alcohols were obtained in high yields with high ees. (C) 2010 Elsevier Science. All rights reserved
\end{abstract}

Keywords: Asymmetric reduction, Ketone, Acyl silane, Meerwein-Ponndorf-Verley reduction, Oppenauer oxidation

\section{Introduction}

Meerwein-Ponndorf-Verley (MPV) reduction of ketone has distinguishing usefulness in organic synthesis. ${ }^{1}$ A stoichiometric amount of metal alkoxides (usually aluminum triisopropoxide) is usually employed as a reducing agent, and the metal part plays an important role in the MPV reduction: it activates the carbonyl group of ketones to be reduced and promotes hydride transfer from the $\mathrm{C}-\mathrm{H}$ bond of the alkoxide. Though extensive efforts have been made to develop a catalytic method of MPV reduction, ${ }^{2,3}$ there had been no report of metal-free MPV reduction of ketone with alcohol until our previous brief report. ${ }^{4}$ We report here details of asymmetric reduction of ketones and acyl silanes that uses chiral anti-pentane-2,4diol and a catalytic amount of a strong Brønsted acid.

In the course of our study on stereoselective reduction of 24-oxochoresterol derivatives, ${ }^{5}$ we planned aluminum hydride-promoted ring cleavage of chiral acetal $3 .^{6} \mathrm{We}$ attempted to prepare chiral acetal $\mathbf{3}$ from ketone $\mathbf{1}$ and chiral diol 2 by using a catalytic amount $(5 \mathrm{~mol} \%)$ of pyridinium $p$-toluenesulfonate (PPTS) in benzene at reflux with continuous removal of water (Table 1). However, the desired acetal 3 was obtained in only $8 \%$ yield, probably due to steric hindrance around the carbonyl group of ketone 1 (entry 1). ${ }^{7}$ The use of $p$-toluenesulfonic acid (TsOH) instead of PPTS gave acetal 3 also in low (12\%) yield, but alcohol 4 was surprisingly obtained in $4 \%$ yield (entry 2 ). When 2,4-dinitrobenzenesulfonic acid (DNBSA), a stronger Brønsted acid than TsOH, was employed, acetal 3 was not formed at all, but alcohol 4 was obtained in $23 \%$ yield (entry 3). Moreover, stereoselectivity for this reduction $(24-\mathrm{R} / \mathrm{S}=88.5: 11.5)$ was higher than that for Corey-Shibata-Bakshi (CBS) reduction $^{8}\left(24-\mathrm{R} / \mathrm{S}=76: 24,{ }^{5}\right.$ Scheme 1).

Table 1. Brønsted acid-controlled selectivity between acetalization and reduction of ketone 1 with diol 2<smiles>[R]CCC(=O)C(C)C</smiles>

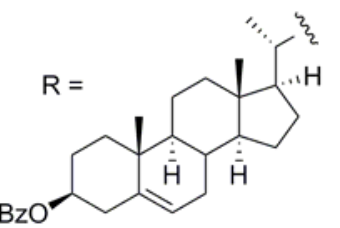

\begin{tabular}{lllll}
\hline Entry & Catalyst & Time $(\mathrm{h})$ & $\mathbf{3}\left(\%\right.$ yield $\left.^{\mathrm{a}}\right)$ & $\mathbf{4}\left(\%\right.$ yield $\left.^{\mathrm{a}}\right)$ \\
\hline 1 & PPTS & 34 & 8 & 0 \\
2 & TsOH & 6 & 12 & 4 \\
3 & DNBSA $^{\mathrm{b}}$ & 2 & 0 & $23^{\mathrm{c}}$ \\
\hline
\end{tabular}

${ }^{\mathrm{a}}$ Isolated yield.

${ }^{\mathrm{b}}$ 2,4-Dinitrobenzenesulfonic acid.

${ }^{c} 24-\mathrm{R} / \mathrm{S}=88.5: 11.5$ 
Scheme 1. CBS reduction of 1

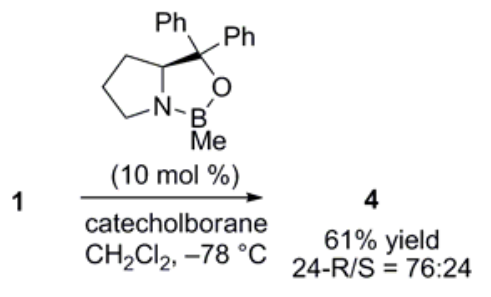

\section{Results and Discussion}

\subsection{Asymmetric reduction of ketones}

Various Brønsted acids were further tested for the reaction of ketone 5 with chiral diol $\mathbf{2}$ in order to find an appropriate Brønsted acid catalyst for the reduction of ketones (Table 2 ). In reduction of tert-butyl ketone 5, trifluoroacetic acid (TFA) and TsOH did not work as catalysts (Entries 1 and 2 ), though the use of $\mathrm{TsOH}$ gave alcohol 4 in the reduction of isopropyl ketone $\mathbf{1}$ (Table 1, Entry 2). The steric hindrance of tert-butyl ketone 5 retarded the reduction with 2. The use of stronger Brønsted acids such as 2fluorobenzenesulfonic acid (FBSA) ${ }^{9}$ and 4nitrobenzenesulfonic acid (NBSA) ${ }^{10}$ gave alcohol 6 in $4 \%$ and $3 \%$ yields, respectively, while the use of 2,4dinitrobenzenesulfonic acid $\left(\right.$ DNBSA) ${ }^{11}$ and trifluoromethanesulfonic acid (TfOH) gave alcohol 6 in $13 \%$ and $11 \%$ yields, respectively (Entries 3-5 and 7). Thus, a strong Brønsted acid worked as an effective catalyst for the present reduction, and DNBSA was found to be an appropriate Brønsted acid catalyst. Increasing the amount of DNBSA from 5 to $20 \mathrm{~mol} \%$ resulted in rapid disappearance of diol 2 and lowered the yield of $\mathbf{6}$, probably because acid-catalyzed dehydration of $\mathbf{6}$ took place (Entry 6). Acetalization of tert-butyl ketone 5 with diol 2 was not observed with any of the Brønsted acids shown in Table 2 . In all of the cases described above, optical purity of the reduction product 6 was $>99 \%$ ee $(R)$, and the enantioselectivity did not depend on the Brønsted acid employed.

Next, the reduction of ketone $\mathbf{5}$ with diol $\mathbf{2}$ was carried out in various solvents at reflux (Table 3). The reduction of 5 in toluene gave alcohol 6 in 4\% yield (Entry 2), and the use of halogenated hydrocarbons such as carbon tetrachloride and dichloroethane gave alcohol $\mathbf{6}$ in low yields (Entries 3 and 4). Reduction in other polar solvents such as THF, diisopropyl ether, ethanol, and acetonitrile did not give $\mathbf{6}$. Therefore, benzene was found to be the most suitable solvent for the present reduction.
Table 2. Effects of Brønsted acids in reduction of ketone 5 to alcohol 6 with diol 2

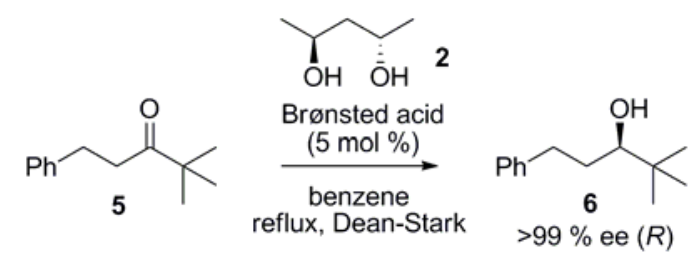

\begin{tabular}{llll}
\hline Entry & Brønsted acid & Time $(\mathrm{h})$ & Isolated Yield $(\%)$ \\
\hline 1 & TFA & 2 & 0 \\
2 & TsOH & 18 & trace \\
3 & FBSA & 5.5 & 4 \\
4 & NBSA & 4 & 3 \\
5 & DNBSA & 4 & 13 \\
$6^{\text {b }}$ & DNBSA & 1.5 & 6 \\
7 & TfOH & 2 & 11
\end{tabular}

${ }^{\text {a }}$ TFA: trifluoroacetic acid; TsOH: p-toluenesulfonic acid; FBSA: 2 fluorobenzenesulfonic acid; NBSA: 4-nitrobenzenesulfonic acid; DNBSA: 2,4-dinitrobenzenesulfonic acid; TfOH: trifluoromethanesulfonic acid.

b $20 \mathrm{~mol} \%$ of DNBSA was used.

Table 3. Effects of solvents in reduction of ketone 5 to alcohol $\mathbf{6}$ with diol $2^{\mathrm{a}}$

\begin{tabular}{llll}
\hline Entry & Solvent & Time (h) & Isolated yield (\%) \\
\hline 1 & benzene & 4 & 13 \\
2 & toluene & 1 & 4 \\
3 & $\mathrm{CCl}_{4}$ & 5 & 5 \\
4 & $\mathrm{ClCH}_{2} \mathrm{CH}_{2} \mathrm{Cl}$ & 1 & 9 \\
\hline
\end{tabular}

${ }^{a}$ Ketone 5 (1.0 equiv), diol 2 (1.1 equiv), and DNBSA (5 mol \%) were used. Reactions were carried out at reflux. In all cases, optical purity of $\mathbf{6}$ was $>99 \%$ ee, which was determined by chiral HPLC.

Various diols were employed in reduction of methyl ketone 7 to alcohol 8 in order to clarify what structural feature of diol was required for the DNBSA-reduction of ketone (Table 4). The effect of methyl groups of diol 2 was first examined by using (3R)-butan-1,3-diol (9) and propane1,3-diol (10). It was found that lack of the methyl substituent of 2 significantly decreased the yield of reduction product 8 from $27 \%$ to $4-9 \%$ (Entries $1-3$ ). It was noted that even diol $\mathbf{1 0}$ reduced ketone 7 by the catalysis of DNBSA. With regard to the stereochemistry of 1,3-diol, anti-configuration was critical for the present reduction because syn-1,3-diol $\mathbf{1 1}$ gave the reduction product $\mathbf{8}$ in a trace amount but gave acetal $\mathbf{1 6}$ in 55\% yield (Entry 4). Also, the use of anti-1,2-diol 12 and anti-1,4diol 13 did not give reduction product $\mathbf{8}$, suggesting that the two hydroxy groups of diol had to be positioned at the 1,3position (Entries 5 and 6). Therefore, anti-1,3-diol structure was found to be required for effective reduction of ketone. The use of $( \pm)$-anti-diol 14, which did not have any 
hydrogens at its 3-position, did not give reduction product 8 but afforded $\beta$-alkoxy ketone 18 in $32 \%$ yield (Entry 7 ).

Table 4. Effects of diols in DNBSA-catalyzed reduction of ketone 7 to alcohol $\mathbf{8}$ in benzene at reflux

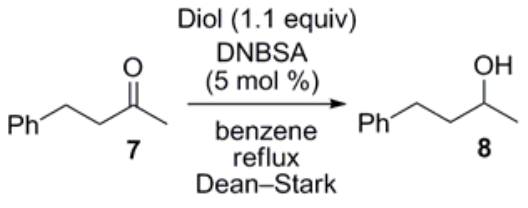

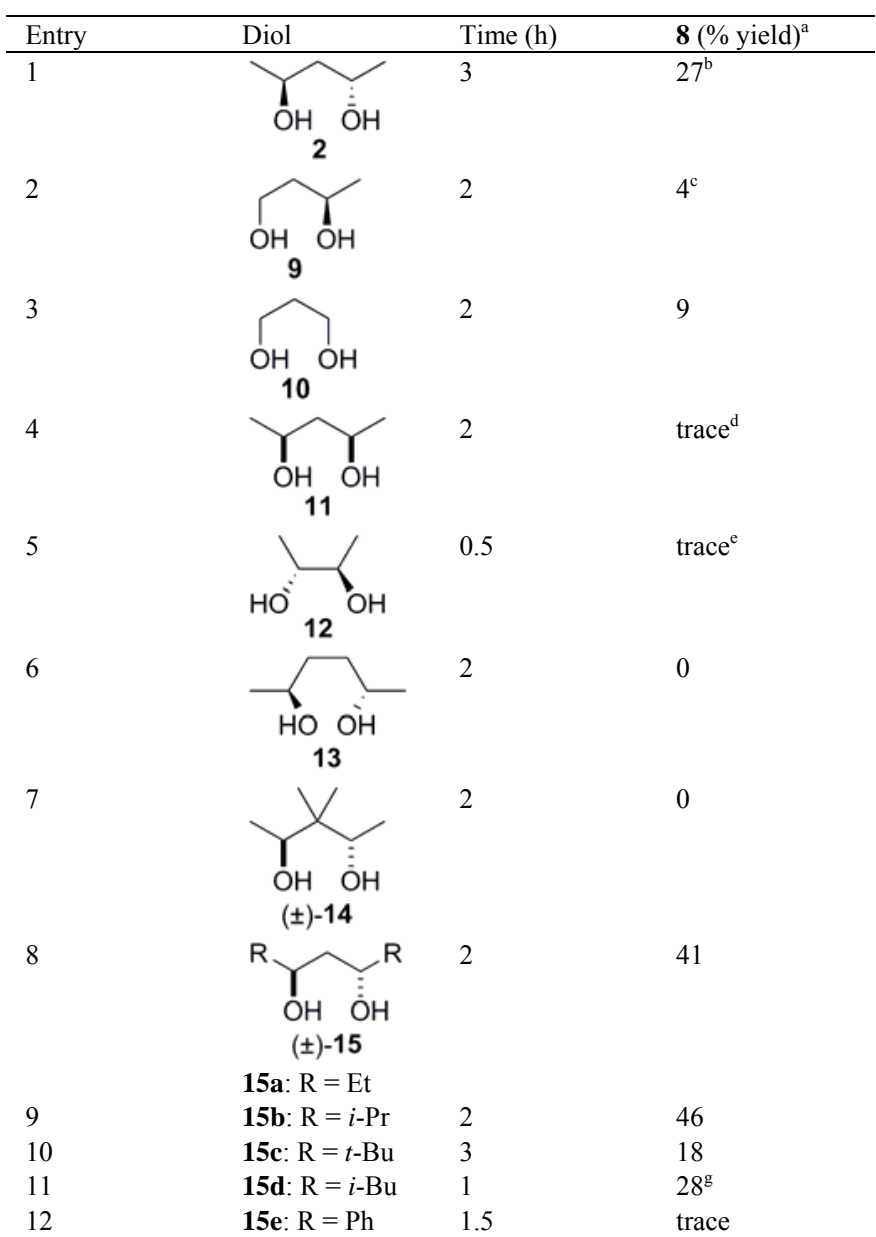

${ }^{\mathrm{a}}$ Isolated yield.

${ }^{\mathrm{b}} 48 \%$ ee $(R)$.

${ }^{\mathrm{c}}$ Ee was not determined.

${ }^{\mathrm{d}}$ Compound 16 was isolated in 55\% yield $(\mathrm{dr}=61: 39)$.

${ }^{\mathrm{e}}$ Compound 17 was isolated in $56 \%$ yield.

${ }^{\mathrm{f}}$ Compound $\mathbf{1 8}$ was isolated in $32 \%$ yield.

${ }^{\mathrm{g}}$ Compound 19 was isolated in $18 \%$ yield (based on 7 ).

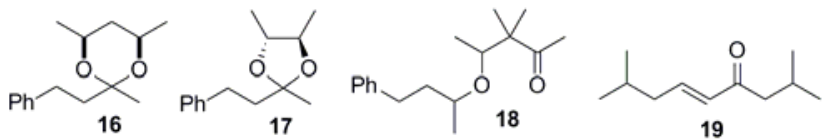

anti-1,3-Diols $( \pm)$-15a-e having various substituents at their 1,3-position were next employed. It was found that as the steric bulkiness increased from methyl to isopropyl groups, the yield of alcohol $\mathbf{8}$ increased, whereas substitution with a tert-butyl group decreased the yield of 8 (Entries 8-10). The use of diol $15 \mathbf{d}(\mathrm{R}=i-\mathrm{Bu})$ resulted in rapid disappearance of $\mathbf{1 5 d}$ and the yield of $\mathbf{8}$ was not improved compared to that in the case of diol 2 . In this case, enone 19 was isolated in 18\% yield (Entry 11). A diol having a phenyl group (15e) did not catalyze the reduction of 7 . Before reduction of 7 , dehydration of benzylic alcohol 15e might proceed under acidic conditions (Entry 12).

A plausible mechanism for reduction of ketone $\mathbf{2 0}$ with diol 15 by catalysis with DNBSA is shown in Scheme 2. Ketone 20 reacts with anti-1,3-diol 15 in the presence of Brønsted acid to give oxocarbenium ion ( 21 or $\mathbf{2 2}$ ). Acetal $\mathbf{2 4}$ can be formed via oxocarbenium ion 22, ${ }^{12}$ but DNBSA, a strong Brønsted acid, catalyzes stereoselective cleavage ${ }^{13}$ of the acetal ring of $\mathbf{2 4}$ to regenerate oxocarbenium ion 22 . Oxocarbenium ion 21, which has two $\mathrm{R}$ groups in equatorial positions, is formed by $\mathrm{C}-\mathrm{C}$ bond rotation in oxocarbenium ion 22. Then 1,5-hydride transfer ${ }^{14}$ proceeds via a six-membered transition state shown in $\mathbf{2 1}$ to form $\beta$ alkoxy ketone 23. Thus, intramolecular MPV reduction and Oppenauer oxidation ${ }^{15}$ proceed in this step. Alcohol 25 and enone $\mathbf{2 6}$ are formed from $\mathbf{2 3}$ by Brønsted acidcatalyzed elimination. The involvement of $\beta$-alkoxy ketone 23 and enone 26 was confirmed by isolation of compounds 18 and 19, respectively.

Scheme 2. Plausible mechanism for DNBSA-catalyzed reduction of ketone 20 to alcohol 25 using anti-1,3-diol 15.

$$
\text { (⿸t) }
$$

Competitive reduction of enone 26 with diol 15 was thought to be the main reason for the low efficiency in DNBSA-catalyzed reduction of ketone 20 with diol $15 .^{16}$ The improved efficiency in the reduction with diol 15b (R $=i$-Pr) was attributed to slow reduction of sterically demanding enone $\mathbf{2 6} \mathbf{b}(\mathrm{R}=i$-Pr). It was then expected that addition of thiol to enone $\mathbf{2 6}$ would give 27, which was less reactive for the reduction with diol $\mathbf{1 5}$ compared with enone 26.

Various thiols 28a-e were used for DNBSA-catalyzed reduction of ketone $\mathbf{7}$ with diol $\mathbf{2}$ in order to improve the efficiency of the reduction (Table 5). It was found that addition of aromatic thiols such as benzenethiol 28a, $O$ methylbenzenethiol 28b, and p-methoxybenzenethiol 28c improved the yield of alcohol 8 (Entries 2-4). Further improvement was observed when aliphatic thiols were used: octanethiol 28d and 2-ethylhexanethiol 28e gave 
alcohol 8 in $62 \%$ and $61 \%$ yields, respectively (Entries 5 and 6). Increasing the amount of diol 2 from 1.1 to 2.0 equivalents did not change the efficiency of the reduction (Compare Entry 5 with Entry 7.). $\beta$-Arylthio or $\beta$-alkylthio pentan-2-ones 29a-e, which were formed by conjugate addition of thiol to in situ-formed enone, were isolated in all cases. However, alcohols $\mathbf{3 0 a}-\mathbf{e}$, which were formed by reduction of $\mathbf{2 9 a}-\mathbf{e}$ with diol $\mathbf{2}$, were also obtained. These results suggested that DNBSA-catalyzed reduction of ketone 7 with diol 2 was improved by adding octanethiol, but consumption of diol 2 , which resulted from competitive reduction of ketone $\mathbf{2 9}$, was not inhibited.

Table 5. Effects of thiols 28a-e in DNBSA-catalyzed reduction of ketone 7 to alcohol 8 in benzene at reflux
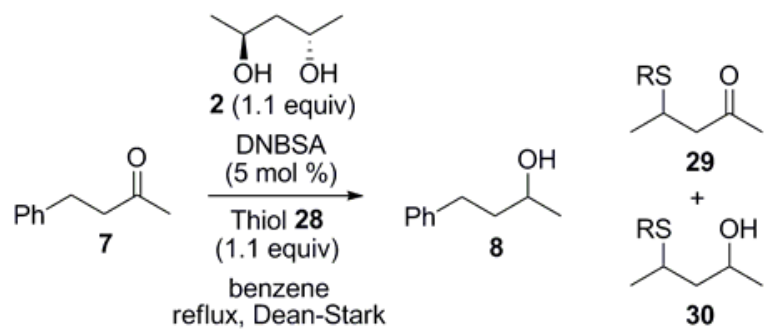

\begin{tabular}{lllllll}
\hline Entry & Thiol & $\mathbf{2 8}$ & Time (h) & $\mathbf{8}^{\mathbf{a}}$ & $\mathbf{2 9}^{\mathbf{a}}$ & $\mathbf{3 0}^{\mathbf{a}}$ \\
\hline 1 & none & & 3 & 27 & - & - \\
2 & $\mathrm{PhSH}$ & $\mathbf{2 8 a}$ & 3 & 40 & 18 & 5 \\
3 & $o-\mathrm{MeC}_{6} \mathrm{H}_{4} \mathrm{SH}$ & $\mathbf{2 8 b}$ & 2.5 & 50 & 44 & 9 \\
4 & $p-\mathrm{MeOC}_{6} \mathrm{H}_{4} \mathrm{SH}$ & $\mathbf{2 8 c}$ & 2.5 & 50 & 56 & 12 \\
5 & $\mathrm{C}_{8} \mathrm{H}_{17} \mathrm{SH}$ & $\mathbf{2 8 d}$ & 3.5 & 62 & 55 & 16 \\
6 & $\mathrm{BuCHEtCH}_{2} \mathrm{SH}$ & $\mathbf{2 8 e}$ & 2.5 & 61 & 55 & 15 \\
$7^{\mathrm{b}}$ & $\mathrm{C}_{8} \mathrm{H}_{17} \mathrm{SH}$ & $\mathbf{2 8 d}$ & 3 & 62 & 61 & 24
\end{tabular}

${ }^{a}$ Isolated yield (\%) based on 7 .

${ }^{\mathrm{b}}$ Two equivalents of diol 2 were employed.

Effects of substituents of diol $\mathbf{1 5}$ bearing ethyl, propyl, isopropyl, and isobutyl groups as the $\mathrm{R}$ group in the reduction of ketone 7 were investigated again in the presence of octanethiol (Table 6). Compared with diol 2 , the use of 15a $(\mathrm{R}=\mathrm{Et})$ and 15b $(\mathrm{R}=i$-Pr) did not improve the yield of alcohol 8 (Entries 1, 2, and 4), though diols 15a and $15 b$ clearly improved the efficiency of the reduction in the absence of octanethiol (Table 4, Entries 8 and 9). When sterically hindered diol 15b was employed, the addition of octanethiol to in situ-formed enone took place slowly to afford the corresponding $\beta$-octylthio ketone 31b in $32 \%$ yield, which was lower than that in the case of diol $2(55 \%)$ (Entries 1 and 4$)$. Insufficient trapping of enone with octanethiol might cause the undesired reduction of enone with diol, which was the reason why further improvement was not observed when sterically demanding diols were employed in the presence of octanethiol. Therefore, the combination of octanethiol and diol 2, which is commercially available as a chiral compound, was employed in the following experiments as optimized conditions.
Table 6. Effects of diol $\mathbf{1 5}$ in DNBSA-catalyzed reduction of ketone $\mathbf{7}$ to alcohol 8 in the presence of octanethiol

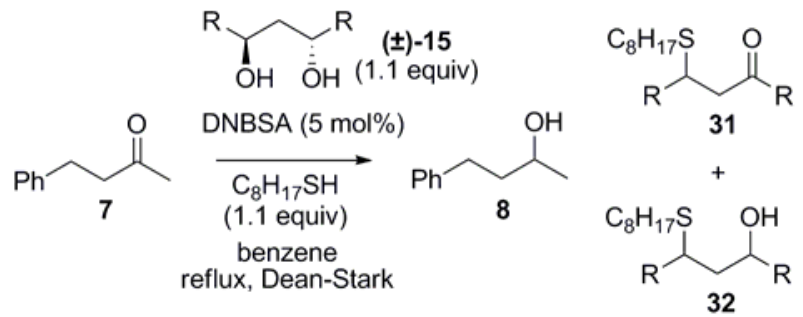

\begin{tabular}{llllll}
\hline Entry & Diol (R) & Time (h) & $\mathbf{8}^{\mathbf{a}}$ & $\mathbf{3 1}^{\mathbf{a}}$ & $\mathbf{3 2}^{\mathbf{a}}$ \\
\hline 1 & 2(Me) & 3.5 & 62 & 55 & 16 \\
2 & 15a (Et) & 1.5 & 64 & 52 & 7 \\
3 & 15f $(n-\mathrm{Pr})$ & 1.5 & 62 & 52 & 6 \\
4 & 15b $(i-\mathrm{Pr})$ & 1 & 50 & 32 & 0 \\
5 & 15d $(i-\mathrm{Bu})$ & 2 & 54 & 29 & 0 \\
\hline
\end{tabular}

${ }^{\mathrm{a}}$ Isolated yield (\%) based on 7 .

The scope and limitations of DNBSA-catalyzed asymmetric reduction of ketones $\mathbf{3 3}$ with chiral diol $\mathbf{2}$ were investigated by using octanethiol as an additive (Table 7). Reduction of tert-alkyl ketones such as 33a,b and $\mathbf{5}$ proceeded with high asymmetric induction (99 >99\% ee) in 18 36\% yields (Entries 1-3). Reduction of sec-alkyl methyl ketones 31c-f proceeded to give the corresponding alcohols 34c-f in $42-57 \%$ yields with $82-93 \%$ ees (Entries 4-7), while reduction of isopropyl ketones $\mathbf{3 3 g}$ and 1 proceeded in low yields with moderate selectivities (Entries 8 and 9). The steric hindrance around the carbonyl group of $\mathbf{3 3 g}$ and 1, which was increased by substitution with a longer alkyl chain than the methyl group of $33 \mathbf{c}-\mathbf{f}$, was the reason for the low yields of $\mathbf{3 4 g}$ and $\mathbf{4}$. Reduction of $n$ alkyl methyl ketones $33 \mathbf{h}-\mathbf{j}$ proceeded in $50-64 \%$ yields and with about $50 \%$ ees (Entries 10-12). In reduction of aromatic ketone, acetophenone 33k did not give the desired alcohol 34k (Entry 13). Detection of styrene by TLC analysis suggested that dehydration of the formed benzylic alcohol 34k with DNBSA took place.

Table 7. Asymmetric reduction of various ketones 33 using diol 2 and DNBSA $^{\mathrm{a}}$ 


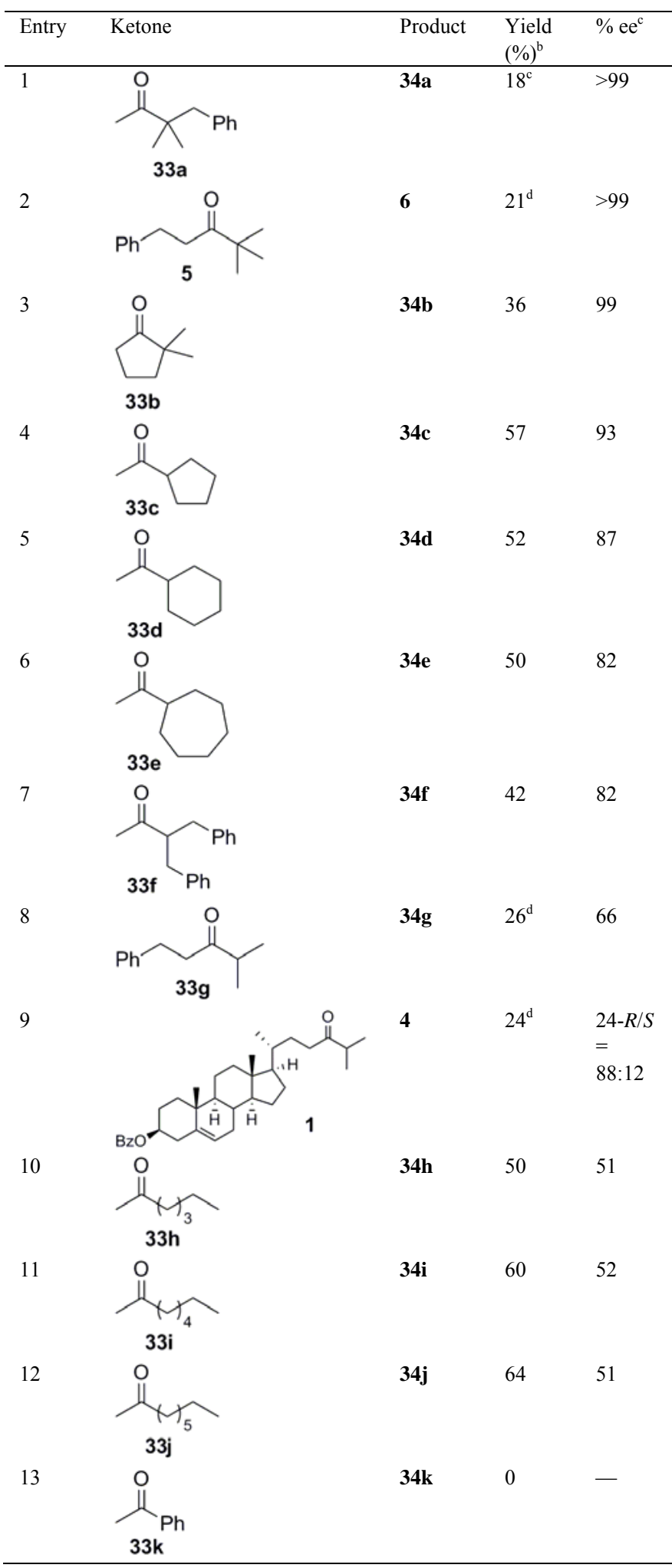

${ }^{\mathrm{a}}$ Ketone (1.0 equiv), diol 2 (1.1 equiv), $\mathrm{C}_{8} \mathrm{H}_{17} \mathrm{SH}$ (1.1 equiv), and DNBSA ( $5 \mathrm{~mol} \%$ ) were refluxed in benzene using a Dean-Stark apparatus.

${ }^{\mathrm{b}}$ Determined by ${ }^{1} \mathrm{H}$ NMR analysis using an internal standard.

${ }^{\mathrm{c}}$ Determined by chiral HPLC (see experimental section).

${ }^{\mathrm{d}}$ Isolated yield.

\subsection{Asymmetric reduction of acyl silanes}

$\alpha$-Hydoxy silanes are useful building blocks in organic synthesis. ${ }^{17}$ Optically active hydroxy silanes have been employed as a chiral auxiliary for oxocarbenium ion, ${ }^{18}$ and they have been used for the synthesis of chiral alcohol by rearrangement of $\alpha$-acetoxy silane. ${ }^{19}$ The present method for reduction of ketone with chiral alcohol 2 was applied to asymmetric reduction $^{20}$ of acyl silanes ${ }^{21}$ for synthesis of optically active $\alpha$-hydroxy silanes.

Attempted reduction of acyl silane $\mathbf{3 5}$ by using diol $\mathbf{2}$ and DNBSA in the presence of octanethiol did not give the desired $\alpha$-hydroxy silane $\mathbf{3 6}$ at all, and alkenyl sulfide $\mathbf{3 7}$ was obtained in $25 \%$ yield (eq 1 ). The formation of alkenyl sulfide by the reaction of acyl silane and thiol has already been reported, ${ }^{22}$ and this result suggested that the reaction of acyl silane $\mathbf{3 5}$ and octhanethiol took place preferentially compared to the reduction of acyl silane 35 with diol 2 . Therefore, the reduction of $\mathbf{3 5}$ with diol $\mathbf{2}$ was carried out in the absence of octanethiol. It was surprisingly found that the reduction of $\mathbf{3 5}$ proceeded very smoothly to afford $\alpha$ hydroxy silane 34 in $83 \%$ yield with high enantioselectivity $(98 \%$ ee $(R)$, eq 2$)$. This result suggested that the reduction of acyl silane 35 with diol $\mathbf{2}$ proceeded more rapidly than the reaction with pent-3-en-2-one which is formed from diol 2 (see Scheme 2). The high reactivity of acyl silane can be ascribed to its higher HOMO level, which is caused by interaction of the $\mathrm{C}-\mathrm{Si}$ bond $\left(\sigma_{\mathrm{C}-\mathrm{Si}}\right)$ with lone pair electrons of the carbonyl group $\left(\mathrm{n}_{\mathrm{o}}\right)^{23}$

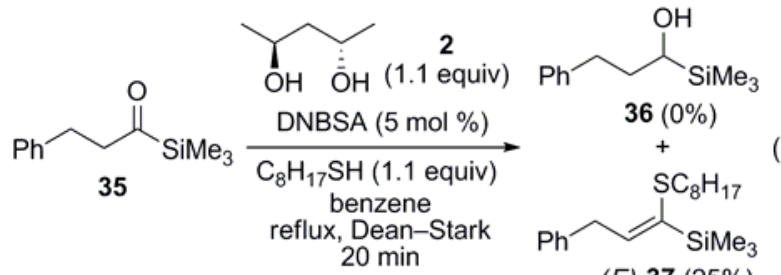

(E)-37 (25\%)

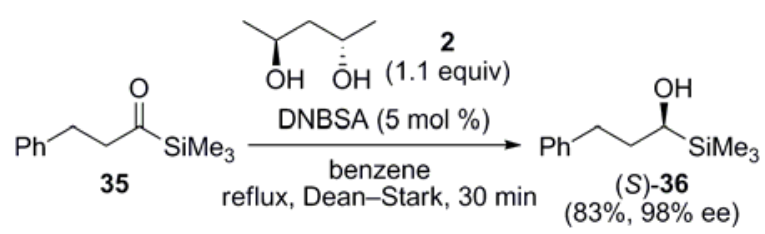

Asymmetric reduction of various acyl silanes 38 was performed by using chiral diol 2 and a catalytic amount of DNBSA in benzene at reflux (Table 8). Asymmetric reduction of octanoyl silanes $\mathbf{3 8 a}-\mathbf{c}$ bearing a trimethylsilyl, $t$-butyldimethylsilyl, or dimethylphenylsilyl group proceeded smoothly to afford the corresponding $\alpha$-hydroxy silanes 39a-c in good yields with high enantioselectivities (Entries 1-3). It was noted that asymmetric reduction of acetyl silane 38d proceeded within 5 min, and alcohol 38d was obtained in $85 \%$ yield with $95 \%$ ee (Entry 5), while prolonged reaction time $(10 \mathrm{~min})$ resulted in $77 \%$ yield of 39d with $75 \%$ ee. Thus, the formed $\alpha$-hydroxy silane 39d was decomposed by extending the reaction time, and partial racemization took place. Reduction of $\beta$-branched acyl 
Table 8. Asymmetric reduction of various acyl silanes 38 using diol 2 and DNBSA ${ }^{\text {a }}$

\begin{tabular}{|c|c|c|c|c|c|}
\hline Entry & Acyl silanes 38 & Time (min) & Product 39 & Yield $(\%)^{b}$ & $\% \mathrm{ee}^{\mathrm{c}}$ \\
\hline 1 & $38 a$ & 30 & $39 a$ & 81 & 98 \\
\hline 2 & $38 b$ & 60 & $39 b$ & 74 & 99 \\
\hline 3 & $38 c$ & 30 & $39 c$ & 78 & 92 \\
\hline 4 & $38 d$ & 5 & $39 d$ & 85 & 95 \\
\hline 5 & $38 \mathrm{e}$ & 120 & & 51 & 97 \\
\hline 6 & $38 \mathrm{f}$ & 180 & $39 f$ & 0 & - \\
\hline 7 & $38 \mathrm{~g}$ & 10 & & 0 & - \\
\hline 8 & $38 \mathrm{~h}$ & 90 & $39 \mathrm{~h}$ & 17 & 74 \\
\hline
\end{tabular}

\footnotetext{
${ }^{\mathrm{a}}$ For conditions, see eq 2.

${ }^{\mathrm{b}}$ Isolated yield.

${ }^{\mathrm{b}}$ Determined by chiral HPLC (see experimental section).
}

silane 38e proceeded in 55\% yield with $97 \%$ ee (Entry 5), but the reduction of $\alpha$-branced acyl silane $\mathbf{3 8 f}$ did not proceed (Entry 6). Reduction of enoyl silane 38g did not give the desired $\alpha$-hydroxy silane $\mathbf{3 9 g}$, probably due to dehydration of $\mathbf{3 9 g}$ under acidic conditions (Entry 7). Asymmetric reduction of benzoyl silane $38 \mathrm{~h}$ proceeded very slowly, and the desired product $\mathbf{3 9 h}$ was obtained in only $17 \%$ yield with $74 \%$ ee (Entry 8 ).

\section{Conclusion}

Asymmetric reduction of aliphatic ketones proceeded by reaction with chiral pentane-2,4-diol 2 in the presence of octanethiol and a catalytic amount of DNBSA in benzene at reflux. On the other hand, asymmetric reduction of various acyl silanes using DNBSA and diol 2 proceeded efficiently in the absence of octanethiol. Highly asymmetric induction was observed when two substituents attached on the carbonyl group of ketone and acyl silane were sterically well-differentiated, and reduction of ketones and acyl silanes bearing less-hindered substituents proceeded more smoothly. It is generally believed that Brønsted acidcatalyzed reaction of ketone and 1,3-diol gives the corresponding acetal, but the present findings show that reduction can take place when a strong Brønsted acid and some anti-1,3-diols are employed.

\section{Experimental section}

All melting points were determined on a Yanagimoto micro melting point apparatus and are uncorrected. Infrared (IR) spectra were recorded on a Shimadzu FTIR-8100. H NMR spectra were recorded on a JEOL JNM EX270 (270 $\mathrm{MHz}$, JEOL JNM ECS400 (400 MHz), JEOL JNM GSX500 (500 MHz), or JEOL JNM ECA600 (600 HMz) spectrometer; chemical shifts $(\delta)$ are reported in parts per million relative to tetramethylsilane. Splitting patterns are designated as $\mathrm{s}_{p_{3}}$ singlet; $\mathrm{d}$, doublet; $\mathrm{t}$, triplet; $\mathrm{q}$, quartet; and $\mathrm{m}$, multiplet. $\mathrm{C}$ NMR spectra were recorded on a JEOL JNM EX270 (67.5 MHz), JEOL JNM ECS400 (100 MHz), JEOL JNM GSX500 (125 MHz), or JEOL JNM ECA600 $(150 \mathrm{HMz})$ spectrometer with complete proton decoupling. Chemical shifts are reported in parts per million relative to tetramethylsilane with solvent resonance as the internal standard $\mathrm{CDCl}_{3}$. High resolution mass spectra (HRMS) were recorded on a JEOL JMS-SX-102A mass 
spectrometer (EI). Elemental analyses were carried out on a Yanaco CHN Corder MT-5. Analytical TLC was performed on Merck precoated TLC plates (silica gel 60 GF254, $0.25 \mathrm{~mm}$ ). Silica gel column chromatography was carried out on silica gel 60N (Kanto Kagaku Co., Ltd., spherical, neutral, 63-210 $\mu \mathrm{m})$. Preparative thin-layer chromatography (PTLC) was carried out on silica gel Wakogel B-5F. (2S,4S)-Pentane-2,4-diol (2) was purchased from Wako Pure Chemical Industries, Ltd. and used without purification (Lot No. ALQ4465, 97.0\% ee, $[\alpha]_{D}^{20}+52.9$ (c 10, EtOH)). Characterization data of compounds $3,4,6,8,16,29 d, 30 d, 34 c-f, 36$, and 39a-d were reported. ${ }^{4}$ Diols $\mathbf{1 5 a},{ }^{24}, \mathbf{1 5 b},{ }^{25}, \mathbf{1 5 c},{ }^{25}, \mathbf{1 5 d}{ }^{25}$ and $\mathbf{1 5 \mathbf { e } ^ { 2 6 }}$ are known compounds. Acyl silanes $\mathbf{3 5},{ }^{27} \mathbf{3 8 a},{ }^{28}$ $\mathbf{3 8 b},{ }^{29} \mathbf{3 8 c},{ }^{30} \mathbf{3 8 d},{ }^{30} \mathbf{3 8 e}, \mathbf{3 8 f}, \mathbf{3 8 g},{ }^{31}$ and $\mathbf{3 8} \mathbf{h}^{32}$ were prepared by the reported procedure. ${ }^{27}$ The absolute configuration was determined by converting alcohol to the corresponding MTPA ester. ${ }^{33}$

\section{(4R,5R)-4,5-Dimethyl-2-methyl-2-(2-phenylethyl)-1,3- dioxolane (17)}

To a stirred mixture of $7(50.2 \mathrm{mg}, 0.34 \mathrm{mmol})$ and $(2 R, 3 R)$-butanediol 12 (34.2 $\mathrm{mg}, 0.38 \mathrm{mmol})$ in dry benzene $(10 \mathrm{~mL})$ was added 2,4-dinitrobenzenesulfonic acid $(4.9 \mathrm{mg}, 0.017 \mathrm{mmol}$ ) and the mixture was refluxed for $0.5 \mathrm{~h}$ with continuous azeotropic removal of water. After cooling to room temperature, the reaction was quenched with saturated aqueous $\mathrm{NaHCO}_{3}$ solution, and the mixture was extracted with ethyl acetate. The combined organic extracts were washed with brine, dried over anhydrous sodium sulfate, filtered, and concentrated. The crude product was purified by preparative TLC (hexane/ethyl acetate $=5: 1)$ to afford $17(41.7 \mathrm{mg}, 0.19$ mmol, $56 \%$ ) as a colorless oil; ${ }^{1} \mathrm{H}$ NMR $\left(600 \mathrm{MHz}, \mathrm{CDCl}_{3}\right)$ $\delta 1.26(\mathrm{~d}, J=2.7 \mathrm{~Hz}, 3 \mathrm{H}), 1.27(\mathrm{~d}, J=3.4 \mathrm{~Hz}, 3 \mathrm{H}), 1.40(\mathrm{~s}$, $9 \mathrm{H}), 1.96(\mathrm{~m}, 2 \mathrm{H}), 2.69-2.78(\mathrm{~m}, 2 \mathrm{H}), 3.60-3.64(\mathrm{~m}, 1 \mathrm{H})$, 3.69-3.72 (m, 1H), 7.16-7.21 (m, 3H), 7.24-7.28 (m, 2H); ${ }^{13} \mathrm{C} \mathrm{NMR}\left(150 \mathrm{MHz}, \mathrm{CDCl}_{3}\right) \delta 16.4,17.2,25.9,30.1,42.2$, 78.1, 79.0, 108.7, 125.6, 128.3, 142.2; IR $\left(\mathrm{CHCl}_{3}, \mathrm{~cm}^{-1}\right)$ 1604, 1454; HRMS (EI+) calcd for $\mathrm{C}_{14} \mathrm{H}_{20} \mathrm{O}_{2}(\mathrm{~m} / \mathrm{z})$ 220.14633 , found 220.14580 .

\section{2,8-Dimethylnon-5-en-4-one (19)}

Obtained as a colorless oil. ; ${ }^{1} \mathrm{H}$ NMR $\left(600 \mathrm{MHz}, \mathrm{CDCl}_{3}\right) \delta$ $0.92(\mathrm{~d}, J=4.8 \mathrm{~Hz}, 6 \mathrm{H}), 0.94$ (d, $J=4.8 \mathrm{~Hz}, 6 \mathrm{H}), 1.77$ (sep, $J=6.9 \mathrm{~Hz}, 1 \mathrm{H}), 2.10(\mathrm{t}, J=7.6 \mathrm{~Hz}, 2 \mathrm{H}), 2.15(\mathrm{~m}, 1 \mathrm{H}), 2.40$ $(\mathrm{d}, J=6.9 \mathrm{~Hz}, 2 \mathrm{H}), 6.07,(\mathrm{~d}, J=15.8 \mathrm{~Hz}, 1 \mathrm{H}), 6.79(\mathrm{dt}, J=$ 15.8, 7.6 Hz, 1H); ${ }^{13} \mathrm{C}$ NMR $\left(150 \mathrm{MHz}, \mathrm{CDCl}_{3}\right) \delta 22.4$, 22.7, 25.2, 27.9, 41.7, 49.1, 131.8, 146.2, 200.6; IR $\left(\mathrm{CHCl}_{3}\right.$, $\mathrm{cm}^{-1}$ ) 1662, 1623, 1465; HRMS (EI+) calcd for $\mathrm{C}_{11} \mathrm{H}_{20} \mathrm{O}$

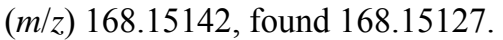

\section{4-Octylsulfanylpentan-2-one (29d)}

Obtained as a colorless oil: ${ }^{1} \mathrm{H}$ NMR $\left(600 \mathrm{MHz}, \mathrm{CDCl}_{3}\right) \delta$ $0.88(\mathrm{t}, J=6.6 \mathrm{~Hz}, 3 \mathrm{H}), 1.24-1.32(\mathrm{~m}, 10 \mathrm{H}), 1.35-1.38(\mathrm{~m}$, $3 \mathrm{H}) 1.57$ (quin, $J=7.56,2 \mathrm{H}), 2.16,(\mathrm{~s}, 3 \mathrm{H}), 2.52(\mathrm{t}, J=$ $7.56,2 \mathrm{H}), 2.57(\mathrm{dd}, J=8.2,17.2 \mathrm{~Hz}, 1 \mathrm{H}), 2.73(\mathrm{dd}, J=6.2$, $17.2 \mathrm{~Hz}, 1 \mathrm{H}), 3.23$ (sex, $J=6.2 \mathrm{~Hz}, 1 \mathrm{H}) ;{ }^{13} \mathrm{C}$ NMR $(150$ $\left.\mathrm{MHz}, \mathrm{CDCl}_{3}\right) \delta 14.0,21.5,22.5,28.8,28.9,29.0,29.6$,
30.5, 30.6, 31.7, 34.8, 50.9, 206.6; IR $\left(\mathrm{CHCl}_{3}, \mathrm{~cm}^{-1}\right)$ 1713, 1456; HRMS (EI+) calcd for $\mathrm{C}_{13} \mathrm{H}_{26} \mathrm{SO}(\mathrm{m} / \mathrm{z}) 230.17044$, found 230.17032 .

\section{4-Octylsulfanylpentan-2-ol (30d)}

Obtained as a colorless oil.; ${ }^{1} \mathrm{H} \mathrm{NMR}\left(600 \mathrm{MHz}, \mathrm{CDCl}_{3}\right.$, a mixture of diastereomers, $57: 43) \delta 0.88(\mathrm{t}, J=6.9 \mathrm{~Hz}, 3 \mathrm{H})$, $1.20(\mathrm{~d}, J=6.2 \mathrm{~Hz}, 3 \mathrm{H}), 1.25-1.40(\mathrm{~m}, 13 \mathrm{H}), 1.55-1.61(\mathrm{~m}$, $3 \mathrm{H}), 1.65-1.71(\mathrm{~m}, 1 \mathrm{H}), 2.55$ (t, $J=7.6 \mathrm{~Hz}, 2 \mathrm{H}), 2.87$ (sex, $J=6.9 \mathrm{~Hz}, 0.44 \mathrm{H}), 2.98(\mathrm{sex}, J=6.9 \mathrm{~Hz}, 0.59 \mathrm{H}), 3.96(\mathrm{~m}$, $0.44 \mathrm{H}), 4.11(\mathrm{~m}, 0.58 \mathrm{H}) ;{ }^{13} \mathrm{C} \mathrm{NMR}\left(150 \mathrm{MHz}, \mathrm{CDCl}_{3}\right) \delta$ $14.1,22.1,22.2,23.7,23.9,29.0,29.1,29.2,29.7,29.8$, 29.9, 30.2, 31.8, 37.0, 38.1, 45.2, 45.7, 65.4, 67.0; IR $\left(\mathrm{CHCl}_{3}, \mathrm{~cm}^{-1}\right)$ 3567, 1456; HRMS (EI+) calcd for $\mathrm{C}_{13} \mathrm{H}_{28} \mathrm{SO}(\mathrm{m} / \mathrm{z}) 232.18609$, found 232.18592.

\section{5-Octylsulfanylheptan-3-one (31a)}

Obtained as a colorless oil: ${ }^{1} \mathrm{H}$ NMR $\left(600 \mathrm{MHz}, \mathrm{CDCl}_{3}\right) \delta$ $0.88(\mathrm{t}, J=7.6 \mathrm{~Hz}, 3 \mathrm{H}), 0.98(\mathrm{t}, J=7.6 \mathrm{~Hz}, 3 \mathrm{H}), 1.07(\mathrm{t}, J$ $=7.6 \mathrm{~Hz}, 3 \mathrm{H}), 1.24-1.38(\mathrm{~m}, 10 \mathrm{H}), 1.53-1.62(\mathrm{~m}, 4 \mathrm{H})$, 2.41-2.50 (m, 4H), 2.59 (dd, $J=6.2,16.5 \mathrm{~Hz}, 1 \mathrm{H}), 2.67$ (dd, $J=7.6,16.5 \mathrm{~Hz}, 1 \mathrm{H}$ ), 3.07 (quin, $J=6.2 \mathrm{~Hz}, 1 \mathrm{H}$ ); ${ }^{13} \mathrm{C}$ NMR $\left(150 \mathrm{MHz}, \mathrm{CDCl}_{3}\right) \delta 7.6,11.2,14.1,22.6,28.2,29.0$, 29.2, 29.8, 31.1, 31.8, 37.0, 42.4, 48.0, 209.8; IR $\left(\mathrm{CHCl}_{3}\right.$, $\left.\mathrm{cm}^{-1}\right)$ 1712, 1459; HRMS (EI+) calcd for $\mathrm{C}_{13} \mathrm{H}_{26} \mathrm{SO}(\mathrm{m} / \mathrm{z})$ 230.17044 , found 230.17032 .

\section{2,6-Dimethyl-5-octylsulfanylheptan-3-one (31b)}

Obtained as a colorless oil: ${ }^{1} \mathrm{H}$ NMR $\left(600 \mathrm{MHz}, \mathrm{CDCl}_{3}\right) \delta$ $0.88(\mathrm{t}, J=6.9 \mathrm{~Hz}, 3 \mathrm{H}), 0.92(\mathrm{~d}, J=6.2 \mathrm{~Hz}, 3 \mathrm{H}), 0.99$ (d, $J$ $=6.9 \mathrm{~Hz}, 3 \mathrm{H}), 1.10(\mathrm{~d}, J=2.1,3 \mathrm{H}), 1.12(\mathrm{~d}, J=2.1 \mathrm{~Hz}$, $3 \mathrm{H}), 1.24-1.38(\mathrm{~m}, 10 \mathrm{H}), 1.53$ (quin, $J=7.6 \mathrm{~Hz}, 2 \mathrm{H}), 1.88$ $(\mathrm{m}, 1 \mathrm{H}), 2.50(\mathrm{t}, J=7.6 \mathrm{~Hz}, 1 \mathrm{H}), 2.60-2.65(\mathrm{~m}, 2 \mathrm{H}), 2.71$ $(\mathrm{dd}, J=8.9,17.2 \mathrm{~Hz}, 1 \mathrm{H}), 3.07(\mathrm{~m}, 1 \mathrm{H}) ;{ }^{13} \mathrm{C}$ NMR $(150$ $\left.\mathrm{MHz}, \mathrm{CDCl}_{3}\right) \delta 14.1,17.9,18.0,18.9,19.6,22.6,28.9$, 29.2, 29.8, 31.8, 32.4, 32.9, 41.6, 44.1, 47.8, 213.1; IR $\left(\mathrm{CHCl}_{3}, \mathrm{~cm}^{-1}\right) 1713,1456$; HRMS (EI+) calcd for $\mathrm{C}_{17} \mathrm{H}_{34} \mathrm{SO}(\mathrm{m} / \mathrm{z})$ 286.23304, found 286.23319.

\section{2,8-Dimethyl-6-octylsulfanylnonan-4-one (31d)}

Obtained as a colorless oil: ${ }^{1} \mathrm{H}$ NMR $\left(600 \mathrm{MHz}, \mathrm{CDCl}_{3}\right) \delta$ 0.86-0.92 (m, 15H), 1.24-1.42 (m, 12H), 1.53-1.57 (m, $2 \mathrm{H}), 1.81(\mathrm{~m}, 1 \mathrm{H}), 2.15(\mathrm{sep}, J=6.9 \mathrm{~Hz}, 1 \mathrm{H}), 2.30(\mathrm{dd}, J=$ 2.7, $6.9 \mathrm{~Hz}, 2 \mathrm{H}), 2.48$ (td, $J=6.9,4.8 \mathrm{~Hz}, 2 \mathrm{H}), 2.55$ (dd, $J$ $=6.9,17.2 \mathrm{~Hz}, 1 \mathrm{H}), 2.68(\mathrm{dd}, J=6.9,17.2 \mathrm{~Hz}, 1 \mathrm{H}), 3.14$ $(\mathrm{m}, 1 \mathrm{H}) ;{ }^{13} \mathrm{C}$ NMR $\left(150 \mathrm{MHz}, \mathrm{CDCl}_{3}\right) \delta 14.1,22.0,22.6$, $22.7,22.9,24.4,25.5,29.0,29.2,29.7,30.6,31.8,38.5$, 44.8, 50.0, 52.7, 209.1; IR $\left(\mathrm{CHCl}_{3}, \mathrm{~cm}^{-1}\right)$ 1708, 1467; HRMS (EI+) calcd for $\mathrm{C}_{19} \mathrm{H}_{38} \mathrm{SO}(\mathrm{m} / \mathrm{z}) 314.26434$, found 314.26412 .

\section{6-Octylsulfanylnonan-4-one (31f)}

Obtained as a colorless oil: ${ }^{1} \mathrm{H}$ NMR $\left(600 \mathrm{MHz}, \mathrm{CDCl}_{3}\right) \delta$ $0.88(\mathrm{t}, J=6.9 \mathrm{~Hz}, 3 \mathrm{H}), 0.89-0.93(\mathrm{~m}, 6 \mathrm{H}), 1.24-1.32(\mathrm{~m}$, $8 \mathrm{H}), 1.34-1.64(\mathrm{~m}, 10 \mathrm{H}), 2.40(\mathrm{td}, J=6.9,4.8 \mathrm{~Hz}, 2 \mathrm{H})$, $2.49(\mathrm{td}, J=7.6,2.1 \mathrm{~Hz}, 2 \mathrm{H}), 2.60(\mathrm{dd}, J=6.9,17.2 \mathrm{~Hz}$, 1H), 2.67 (dd, $J=6.9,17.2 \mathrm{~Hz}, 1 \mathrm{H}$ ), 3.11 (quin, $J=6.9 \mathrm{~Hz}$, $1 \mathrm{H}) ;{ }^{13} \mathrm{C}$ NMR $\left(150 \mathrm{MHz}, \mathrm{CDCl}_{3}\right) \delta 13.7,13.9,14.1,17.1$, 
20.0, 22.6, 29.0, 29.2, 29.8, 31.0, 31.8, 37.6, 40.4, 45.7, 48.9, 209.4; IR $\left(\mathrm{CHCl}_{3}, \mathrm{~cm}^{-1}\right)$ 1710, 1465; HRMS (EI+) calcd for $\mathrm{C}_{17} \mathrm{H}_{34} \mathrm{SO}(\mathrm{m} / \mathrm{z})$ 286.23304, found 286.23317.

\section{5-Octylsulfanylheptan-3-ol (32a)}

Obtained as a colorless oil: ${ }^{1} \mathrm{H}$ NMR $\left(600 \mathrm{MHz}, \mathrm{CDCl}_{3}\right.$, a mixture of diastereomers, $56: 44) \delta 0.88(\mathrm{t}, J=6.9 \mathrm{~Hz}, 3 \mathrm{H})$, 0.94-0.97 (m, 3H), 0.98-1.02 (m, 3H), 1.22-1.72 (m, 18H), 2.15 (brs, $0.33 \mathrm{H}), 2.48-2.55(\mathrm{~m}, 2 \mathrm{H}), 2.62-2.67(\mathrm{~m}, 0.55 \mathrm{H})$, 2.78 (dtd, $J=4.1,6.9,9.6 \mathrm{~Hz}, 0.43 \mathrm{H}$ ), 2.92 (brs, $0.46 \mathrm{H}$ ), $3.70(\mathrm{~m}, 0.54 \mathrm{H}), 3.87(\mathrm{~m}, 0.42 \mathrm{H}) ;{ }^{13} \mathrm{C}$ NMR $(150 \mathrm{MHz}$, $\left.\mathrm{CDCl}_{3}\right) \delta 9.8,10.0,11.0,11.4,14.1,22.6$, ; IR $\left(\mathrm{CHCl}_{3}, \mathrm{~cm}^{-}\right.$ $\left.{ }^{1}\right) 3417,1463$; HRMS (EI+) calcd for $\mathrm{C}_{15} \mathrm{H}_{32} \mathrm{SO}(\mathrm{m} / \mathrm{z})$ 260.21739 , found 260.21735 .

\section{6-Octylsulfanylnonan-4-ol (32f)}

Obtained as a colorless oil: ${ }^{1} \mathrm{H}$ NMR $\left(600 \mathrm{MHz}, \mathrm{CDCl}_{3}\right.$, a mixture of diastereomers, $55: 45) \delta 0.88(\mathrm{t}, J=6.9 \mathrm{~Hz}, 3 \mathrm{H})$, $0.938 \mathrm{~m}, 6 \mathrm{H}), 1.22-1.32(\mathrm{~m}, 9 \mathrm{H}), 1.34-1.72(\mathrm{~m}, 13 \mathrm{H}), 2.21$ (brs, $0.37 \mathrm{H}), 2.46-2.55(\mathrm{~m}, 2 \mathrm{H}), 2.68(\mathrm{~m}, 0.54 \mathrm{H}), 2.84(\mathrm{~m}$, $0.45 \mathrm{H}), 2.95$ (brs, $0.46 \mathrm{H}), 3.78(\mathrm{~m}, 0.53 \mathrm{H}), 3.95(\mathrm{~m}$, $0.43 \mathrm{H}) ;{ }^{13} \mathrm{C} \mathrm{NMR}\left(150 \mathrm{MHz}, \mathrm{CDCl}_{3}\right) \delta 14.00,14.09,18.66$, $19.82,20.11,22.64,29.04,29.06,29.16,29.18,29.20$, $29.76,29.78,29.83,30.10,31.80,37.97,38.00,40.04$, 40.06, 41.24, 42.05, 42.29, 44.28, 69.04, 71.30; IR $\left(\mathrm{CHCl}_{3}\right.$, $\mathrm{cm}^{-1}$ ) 3419, 1465; HRMS (EI+) calcd for $\mathrm{C}_{17} \mathrm{H}_{36} \mathrm{SO}(\mathrm{m} / \mathrm{z})$ 288.24869 , found 288.24866

\section{General procedure for asymmetric reduction of ketones (Table 7, entry 4)}

To a stirred mixture of 33c (49.4 mg, $0.44 \mathrm{mmol}),(2 S, 4 S)$ pentane-2,4-diol (2) (49.8 mg, $0.48 \mathrm{mmol})$, and 2,4dinitrobenzenesulfonic acid (DNBSA, $6.3 \mathrm{mg}, 0.022 \mathrm{mmol}$ ) in dry benzene $(5 \mathrm{~mL})$ was added a solution of 1octanethiol $(70.5 \mathrm{mg}, 0.48 \mathrm{mmol})$ in dry benzene $(5 \mathrm{~mL})$, and the mixture was refluxed for $1.5 \mathrm{~h}$ with continuous azeotropic removal of water. After cooling to room temperature, the reaction was quenched with saturated aqueous $\mathrm{NaHCO}_{3}$ solution, and the mixture was extracted with ether. The combined organic extracts were washed with brine, dried over anhydrous sodium sulfate, filtered, and concentrated. The crude product was purified by column chromatography on silica gel (hexane/ $\mathrm{Et}_{2} \mathrm{O}=40 / 1$ ) to afford $34 \mathbf{c}^{4}$ (28.5 $\mathrm{mg}, 0.25 \mathrm{mmol} 57 \%$ ) as a colorless oil.

\section{(R)-3,3-Dimethyl-4-phenyl-butan-2-ol (34a) ${ }^{34}$}

Compound 34a $(>99 \%$ ee $(R))$ was obtained as a colorless oil. The enantiomeric excess was determined by HPLC analysis using a chiral column. Chiral HPLC: (Daicel Chiralpak AD-H $46 \times 150 \mathrm{~mm}, 254 \mathrm{~nm}$ UV detector, room temperature, eluent: (hexane/i-PrOH) 40:1, flow rate: 0.5 $\mathrm{mL} / \mathrm{min}$, retention time $(\mathrm{min}) 14.4(R$ isomer $) .[\alpha]_{\mathrm{D}}^{22}-7.93$ (c 1.9, $\left.\mathrm{CHCl}_{3}\right)\left(\right.$ lit. $^{34}[\alpha]_{\mathrm{D}}-4.66\left(\right.$ c $\left.\left.3.0, \mathrm{CHCl}_{3}\right)\right) ;{ }^{1} \mathrm{H}$ NMR $\left(600 \mathrm{MHz}, \mathrm{CDCl}_{3}\right) \delta 0.80(\mathrm{~s}, 3 \mathrm{H}), 0.86(\mathrm{~s}, 3 \mathrm{H}), 1.16(\mathrm{~d}, J=$ $6.2 \mathrm{~Hz}, 3 \mathrm{H}), 2.50(\mathrm{~d}, J=13.1 \mathrm{~Hz}, 1 \mathrm{H}), 2.68(\mathrm{~d}, J=13.1 \mathrm{~Hz}$, $1 \mathrm{H}), 3.53$ (q, $J=6.2 \mathrm{~Hz}, 1 \mathrm{H}), 7.16-7.21(\mathrm{~m}, 3 \mathrm{H}), 7.25-$ $7.28(\mathrm{~m}, 2 \mathrm{H}) ;{ }^{13} \mathrm{C} \mathrm{NMR}\left(150 \mathrm{MHz}, \mathrm{CDCl}_{3}\right) \delta ; 17.9,21.7$, 23.0, 38.6, 44.5, 73.7, 125.8, 127.7, 130.5, 138.9.

\section{(R)-2,2-Dimethylcyclopentanol (34b) ${ }^{35}$}

Compound 34b (99\% ee $(R))$ was obtained as a colorless oil. The enantiomeric excess (93\% ee) was determined by HPLC analysis using a chiral column after derivatization to the corresponding p-nitrobenzoate. Chiral HPLC: (Daicel Chiralpak AD-H $46 \times 150 \mathrm{~mm}, 254 \mathrm{~nm}$ UV detector, room temperature, eluent: (hexane/i-PrOH) 200:1, flow rate: 0.5 $\mathrm{mL} / \mathrm{min}$, retention time $(\mathrm{min}) 13.3$ ( $S$ isomer), $14.4(R$

isomer). $[\alpha]_{\mathrm{D}}^{23}-19.49$ (c 0.9 , benzene) (lit. ${ }^{35}[\alpha]_{\mathrm{D}}-15.8$ (c 10.1, benzene)); ${ }^{1} \mathrm{H} \mathrm{NMR}\left(600 \mathrm{MHz}, \mathrm{CDCl}_{3}\right) \delta 0.94(\mathrm{~s}, 3 \mathrm{H})$, $0.96(\mathrm{~s}, 3 \mathrm{H}), 1.35-1.40(\mathrm{~m}, 1 \mathrm{H}), 1.52-1.62(\mathrm{~m}, 1 \mathrm{H}), 1.68-$ $1.77(\mathrm{~m}, 1 \mathrm{H}), 2.00-2.05(\mathrm{~m}, 1 \mathrm{H}), 3.67(\mathrm{t}, J=5.5 \mathrm{~Hz}, 1 \mathrm{H})$; ${ }^{13} \mathrm{C}$ NMR $\left(150 \mathrm{MHz}, \mathrm{CDCl}_{3}\right) \delta ; 19.8,21.2,26.6,32.6,37.4$, 42.0, 81.2.

\section{(R)-2-Methyl-5-phenyl-3-pentanol (34g). ${ }^{36}$}

Compound $34 \mathrm{~g}(66 \%$ ee $(R))$ was obtained as a colorless oil. The enantiomeric excess was determined by HPLC analysis using a chiral column (Daicel Chiralpak AD-H $46 \times 150$ $\mathrm{mm}, 254 \mathrm{~nm}$ UV detector, room temperature, eluent: (hexane/i-PrOH) 20:1, flow rate: $0.5 \mathrm{~mL} / \mathrm{min}$, retention time ( $\mathrm{min}) 10.2$ ( $S$ isomer), $10.9\left(R\right.$ isomer). $[\alpha]_{\mathrm{D}}^{30}+25.19(c$ 3.0, EtOH); ${ }^{1} \mathrm{H}$ NMR (500 MHz, $\left.\mathrm{CDCl}_{3}\right) \delta 0.90(\mathrm{~d}, J=6.8$ $\mathrm{Hz}, 6 \mathrm{H}), 1.61$ (brs, 1H), $1.67(\mathrm{~m}, 1 \mathrm{H}), 2.63$ (m, 1H), 2.83 (ddd, $J=5.210 .0,13.7 \mathrm{~Hz}, 1 \mathrm{H}), 3.37$ (ddd, $J=3.6,5.2,8.8$ $\mathrm{Hz}, 1 \mathrm{H}), 7.15-7.21(\mathrm{~m}, 3 \mathrm{H}), 7.25-7.28(\mathrm{~m}, 2 \mathrm{H}) ;{ }^{13} \mathrm{C} \mathrm{NMR}$ $\left(125 \mathrm{MHz}, \mathrm{CDCl}_{3}\right) \delta 17.1,18.7,32.4,33.6,35.9,76.0$, $125.7,128.3,128.4,142.3$.

\section{(R)-Heptan-2-ol (34h) ${ }^{37}$}

Compound $34 \mathrm{~h}(51 \%$ ee $(R))$ was obtained as a colorless oil. The enantiomeric excess was determined by HPLC analysis using a chiral column after derivatization to the corresponding benzoate. Chiral HPLC: (Daicel Chiralpak AD-H $46 \times 150 \mathrm{~mm}, 254 \mathrm{~nm}$ UV detector, room temperature, eluent: (hexane/i-PrOH) 200:1, flow rate: 0.5 $\mathrm{mL} / \mathrm{min}$, retention time ( $\mathrm{min}) 6.6$ ( $R$ isomer), 7.3 ( $S$ isomer). $[\alpha]_{\mathrm{D}}^{29}-5.54\left(\right.$ c $\left.0.67, \mathrm{CHCl}_{3}\right) ;{ }^{1} \mathrm{H} \mathrm{NMR}\left(400 \mathrm{MHz}, \mathrm{CDCl}_{3}\right) \delta$; $0.89(\mathrm{t}, J=6.9 \mathrm{~Hz}, 3 \mathrm{H}), 1.17(\mathrm{~d}, J=6.0 \mathrm{~Hz}, 3 \mathrm{H}), 1.26-1.48$ $(\mathrm{m}, 9 \mathrm{H}), 3.77(\mathrm{~m}, 1 \mathrm{H}) ;{ }^{13} \mathrm{C} \mathrm{NMR}\left(100 \mathrm{MHz}, \mathrm{CDCl}_{3}\right) \delta 14.0$, 22.6, 23.3, 25.4, 31.8, 39.2, 68.0.

\section{(R)-Octan-2-ol (34i) $)^{35}$}

Compound $34 \mathbf{i}(52 \%$ ee $(R))$ was obtained as a colorless oil. The enantiomeric excess was determined by HPLC analysis using a chiral column after derivatization to the corresponding benzoate. Chiral HPLC: (Daicel Chiralpak $\mathrm{AD}-\mathrm{H} 46 \times 150 \mathrm{~mm}, 254 \mathrm{~nm}$ UV detector, room temperature, eluent: (hexane/i-PrOH) 300:1, flow rate: 0.5 $\mathrm{mL} / \mathrm{min}$, retention time $(\mathrm{min}): 6.6$ ( $R$ isomer), 7.2 ( $S$ isomer). $[\alpha]_{\mathrm{D}}^{20}-4.19$ (c 1.0, $\left.\mathrm{CHCl}_{3}\right)\left(\right.$ lit. $^{35}[\alpha]_{\mathrm{D}}-5.8$ (c 8.8, $\left.\mathrm{CHCl}_{3}\right)$ ); ${ }^{1} \mathrm{H} \mathrm{NMR}\left(400 \mathrm{MHz}, \mathrm{CDCl}_{3}\right) \delta 0.89(\mathrm{~m}, 3 \mathrm{H}), 1.17$ $(\mathrm{d}, J=5.5 \mathrm{~Hz}, 3 \mathrm{H}), 1.22-1.50(\mathrm{~m}, 10 \mathrm{H}), 1.95$ (brs, $1 \mathrm{H})$, $3.77(\mathrm{~m}, 1 \mathrm{H}) ;{ }^{13} \mathrm{C}$ NMR $\left(100 \mathrm{MHz}, \mathrm{CDCl}_{3}\right) \delta 14.0,22.5$, 23.3, 25.7, 29.3, 31.8, 39.3, 68.0. 


\section{(R)-Nonane-2-ol (34j) $)^{38}$}

Compound $34 \mathbf{j}$ (51\% ee $(R))$ was obtained as a colorless oil. The enantiomeric excess was determined by HPLC analysis using a chiral column after derivatization to the corresponding benzoate. Chiral HPLC: (Daicel Chiralpak AD-H $46 \times 150 \mathrm{~mm}, 254 \mathrm{~nm} \mathrm{UV}$ detector, room temperature, eluent: (hexane/i-PrOH ) 300:1, flow rate: 0.5 $\mathrm{mL} / \mathrm{min}$, retention time ( $\mathrm{min}$ ): 6.40 ( $R$ isomer), 6.87 ( $S$

isomer). $[\alpha]_{\mathrm{D}}^{23}-6.35$ (c $\left.0.88, \mathrm{CHCl}_{3}\right)\left(\right.$ lit. $^{38}[\alpha]_{\mathrm{D}}-6.95$ (c 1.1, $\left.\mathrm{CHCl}_{3}\right)$ ); ${ }^{1} \mathrm{H} \mathrm{NMR}\left(600 \mathrm{MHz}, \mathrm{CDCl}_{3}\right) \delta 0.88(\mathrm{t}, J=6.5 \mathrm{~Hz}$, $3 \mathrm{H}), 1.18(\mathrm{~d}, J=6.2 \mathrm{~Hz}, 3 \mathrm{H}), 1.25-1.58(\mathrm{~m}, 13 \mathrm{H}), 3.79$ $(\mathrm{sex}, J=1 \mathrm{H}) ;{ }^{13} \mathrm{C} \mathrm{NMR}\left(150 \mathrm{MHz}, \mathrm{CDCl}_{3}\right) \delta 14.1,22.6$, 23.4, 25.7, 29.3, 29.6, 31.8, 39.3, 68.2.

\section{(Z)-1-Octylsulfanyl-3-phenyl-1-trimethylsilylprop-1-en (37)}

To a stirred mixture of 35 (49.4 mg, $0.24 \mathrm{mmol}),(2 S, 4 S)-$ pentane-2,4-diol 2 (28.5 $\mathrm{mg}, 0.27 \mathrm{mmol})$ and 2,4dinitrobenzenesulfonic acid (DNBSA, $3.4 \mathrm{mg}, 0.012 \mathrm{mmol}$ ) in dry benzene $(5 \mathrm{~mL})$ was added a solution of 1octanethiol $(70.5 \mathrm{mg}, 0.48 \mathrm{mmol})$ in dry benzene $(5 \mathrm{~mL})$, and the mixture was refluxed for $20 \mathrm{~min}$ with continuous azeotropic removal of water. After cooling to room temperature, the reaction was quenched with saturated aqueous $\mathrm{NaHCO}_{3}$ solution, and the mixture was extracted with ethyl acetate. The combined organic extracts were washed with brine, dried over anhydrous sodium sulfate, filtered, and concentrated. The crude product was purified by preparative TLC (hexane/benezene $=20: 1$ ) to afford 37 (20.2 mg, $0.060 \mathrm{mmol}, 25 \%$ ) as a colorless oil; ${ }^{1} \mathrm{H}$ NMR $\left(600 \mathrm{MHz}, \mathrm{CDCl}_{3}\right) \delta 0.17(\mathrm{~s}, 9 \mathrm{H}), 0.88(\mathrm{t}, J=6.9 \mathrm{~Hz}, 3 \mathrm{H})$, $1.22-1.40(\mathrm{~m}, 10 \mathrm{H}), 1.57$ (quin, $J=7.6 \mathrm{~Hz}, 2 \mathrm{H}), 2.65(\mathrm{t}, J$ $=7.6 \mathrm{~Hz}, 2 \mathrm{H}), 3.78(\mathrm{~d}, J=6.2 \mathrm{~Hz}, 2 \mathrm{H}), 6.37(\mathrm{t}, J=6.9 \mathrm{~Hz}$, $1 \mathrm{H}) ;{ }^{13} \mathrm{C}$ NMR $\left(150 \mathrm{MHz}, \mathrm{CDCl}_{3}\right) \delta-0.7,14.1,22.6,28.8$, 29.1, 29.2, 30.1, 31.8, 34.6, 36.9, 125.9, 128.4, 136.9, 140.3, 146.2; IR $\left(\mathrm{CHCl}_{3}, \mathrm{~cm}^{-1}\right)$ 1602, 1247; HRMS (EI+) calcd for $\mathrm{C}_{13} \mathrm{H}_{26} \mathrm{SO}(\mathrm{m} / \mathrm{z}) 230.17044$, found 230.17032. The $(\mathrm{Z})-$ configuration was determined by NOE experiments (between $\underline{\mathrm{CH}}=\mathrm{C}$ and $\underline{\mathrm{Me}}_{3} \mathrm{Si}$ )

\section{General Procedure for Asymmetric Reduction of Acyl Silanes (eq 2)}

\section{Acknowledgments}

This work was partially supported by a Grant-in-Aid for Scientific Research from the Ministry of Education, Culture, Sports, Science, and Technology, Japan. The authors thank Teijin Pharma Ltd. for financial support and also thank Dr. Osamu Nishikawa, Mr. Kenzo Watanabe, Mr. Jun-ichi Oshida, and Mr. Toru Minoshima (all in Teijin Pharma Ltd.) for discussions.
To a stirred mixture of $35(77.0 \mathrm{mg}, 0.37 \mathrm{mmol})$ and $(2 S, 4 S)$-pentane-2,4-diol $2(42.2 \mathrm{mg}, 0.40 \mathrm{mmol})$ in dry benzene $(10 \mathrm{~mL})$ was added 2,4-dinitrobenzenesulfonic acid (DNBSA, $5.3 \mathrm{mg}, 0.019 \mathrm{mmol}$ ), and the mixture was heated at reflux for $0.5 \mathrm{~h}$ with continuous azeotropic removal of water. After cooling to room temperature, the reaction was quenched with saturated aqueous $\mathrm{NaHCO}_{3}$ solution, and the mixture was extracted with ethyl acetate. The combined organic extracts were washed with brine, dried over anhydrous sodium sulfate, filtered, and concentrated. The crude product was purified by column chromatography on silica gel (hexane/ethyl acetate $=20 / 1$ ) to afford $36^{4}(64.3 \mathrm{mg}, 0.31 \mathrm{mmol} 83 \%)$ as a colorless oil.

\section{(S)-1-tert-Butyldimethylsilyl-3-methybutan-1-ol (39e)}

Compound 39e (97\% ee (S)) was obtained as a colorless oil. The enantiomeric excess was determined by HPLC analysis using a chiral column after derivatization to the corresponding $p$-nitrobenzoate. Chiral HPLC: (Daicel Chiralpak OD-H $46 \times 150 \mathrm{~mm}, 254 \mathrm{~nm}$ UV detector, room temperature, eluent: (hexane/i-PrOH ) 400:1, flow rate: 0.5 $\mathrm{mL} / \mathrm{min}$, retention time ( $\mathrm{min}): 7.4$ ( $R$ isomer), 10.7 ( $S$ isomer). $[\alpha]_{\mathrm{D}}^{20}+19.46\left(\right.$ c $\left.0.8, \mathrm{CHCl}_{3}\right) ;{ }^{1} \mathrm{H} \mathrm{NMR}(400 \mathrm{MHz}$, $\left.\mathrm{CDCl}_{3}\right) \delta-0.06(\mathrm{~s}, 3 \mathrm{H}), 0.01(\mathrm{~s}, 3 \mathrm{H}), 0.90(\mathrm{~d}, J=6.9 \mathrm{~Hz}$, $3 \mathrm{H}), 0.94(\mathrm{~m}, 12 \mathrm{H}), 1.17(\mathrm{ddd}, J=2.3,10.5,14.2 \mathrm{~Hz}, 1 \mathrm{H})$, $1.58(\mathrm{ddd}, J=2.3,12.4,14.2 \mathrm{~Hz}, 1 \mathrm{H}), 1.80-1.90(\mathrm{~m}, 1 \mathrm{H})$, $3.59(\mathrm{dd}, J=2.3,12.4 \mathrm{~Hz}, 1 \mathrm{H}) ;{ }^{13} \mathrm{C}$ NMR $(100 \mathrm{MHz}$, $\left.\mathrm{CDCl}_{3}\right) \delta-8.7,-7.7,16.8,20.8,24.0,24.1,27.1,43.4,61.9$; IR $\left(\mathrm{CHCl}_{3}, \mathrm{~cm}^{-1}\right) 1250,1466,3603$.

\section{(S)-a-(Trimethylsilyl) benzyl alcohol (39h) ${ }^{24}$}

Compound $39 \mathbf{h}(74 \%$ ee $(S))$ was obtained as a colorless oil. The enantiomeric excess was determined by HPLC analysis using a chiral column (Daicel Chiralpak OD-H $46 \times 150$ $\mathrm{mm}, 254 \mathrm{~nm}$ UV detector, room temperature, eluent: (hexane/i-PrOH) 20:1, flow rate: $0.5 \mathrm{~mL} / \mathrm{min}$, retention time ( $\mathrm{min}$ ): 8.85 ( $\mathrm{S}$ isomer), 12.2 ( $R$ isomer). $[\alpha]_{\mathrm{D}}^{30}-59.37$ $\left(\right.$ c $\left.0.16, \mathrm{CHCl}_{3}\right)\left(\right.$ lit. $^{20 \mathrm{c}}[\alpha]_{\mathrm{D}}-79.7\left(\right.$ c $\left.\left.1.08, \mathrm{CHCl}_{3}\right)\right) ;{ }^{1} \mathrm{H}$ NMR $\left(600 \mathrm{MHz}, \mathrm{CDCl}_{3}\right) \delta 0.02(\mathrm{~s}, 9 \mathrm{H}), 1.68$ (brs, 1H), 4.53 (s, 1H), 7.16-7.20 (m, 3H), 7.30-7.32 (m, 2H); ${ }^{13} \mathrm{C}$ NMR (150 $\left.\mathrm{MHz}, \mathrm{CDCl}_{3}\right) \delta-4.2,70.6,124.9,125.8,128.1,144.2$.

\section{References}

1. (a) Wilds, A. L. Org. React. 1944, 2, 178; (b) de Graauw, C. F.; Peters, J. A.; van Bekkum, H.; Huskens, J. Synthesis 1994, 1007.

2. (a) Kow, R.; Nygren, R.; Rathke, M. W. J. Org. Chem. 1977, 42, 826; (b) Akamanchi, K. G.; Varalakshmy, N. R. Tetrahedron Lett. 1995, 36, 3571; (c) Ooi, T.; Miura, T.; Maruoka, K. Angew. Chem., Int. Ed. 1998, 37, 2347; (d) Campbell, E. J.; Zhou, H.; Nguyen, S. T. Org. Lett. 2001, 3, 2391; (e) Ooi, T.; Itagaki, Y.; Miura, T.; Maruoka, K. Tetrahedron Lett. 1999, 40, 2137; (f) Gal, G.; Krasznai, I. Magy. Kem. Foly. 1956, 62, 155; (g) Gal, G.; Krasznai, E. Acta Chim. Acad. Sci. Hung. 1958, 17, 171; (h) Ko, B.-T.; Wu, C.-C.; Lin, C.-C. Organometallics 2000, 19, 1864; (i) Konishi, K.; Makita, K.; Aida, T.; Inoue, S. J. Chem. Soc., 
Chem. Commun. 1988, 643; (j) Namy, J. L.; Souppe, J.; Collin, J.; Kagan, H. B. J. Org. Chem. 1984, 49, 2045; (k) Lebrun, A.; Namy, J. L.; Kagan, H. B. Tetrahedron Lett. 1991, 32, 2355.

3. Asymmetric catalysis: (a) Evans, D. A.; Nelson, S. G.; Gagne, M. R.; Muci, A. R. J. Am. Chem. Soc. 1993, 115, 9800; (b) Campbell, E. J.; Zhou, H.; Nguyen SonBinh, T. Angew. Chem., Int. Ed. Engl. 2002, 41, 1020.

4. Matsuo, J.; Hattori, Y.; Ishibashi, H. Org. Lett. 2010, 12, 2294.

5. Matsuo, J.; Kozai, T.; Nishikawa, O.; Hattori, Y.; Ishibashi, H. J. Org. Chem. 2008, 73, 6902.

6. (a) Mori, A.; Fujiwara, J.; Maruoka, K.; Yamamoto, H. Tetrahedron Lett. 1983, 24, 4581; (b) Mori, A.; Fujiwara, J.; Maruoka, K.; Yamamoto, H. J. Organomet. Chem. 1985, 285, 83.

7. Dauben, W. G.; Gerdes, J. M.; Look, G. C. J. Org. Chem. 1986, 51, 4964.

8. (a) Corey, E. J.; Helal, C. J. Angew. Chem., Int. Ed. 1998, 37, 1986; (b) Itsuno, S. Org. React. 1998, 52, 395.

9. Dong, H.; Du, H.; Wickramasinghe, S. R.; Qian, X. J. Phys. Chem. B 2009, 113, 14094

10. Crumrine, D. S.; Shankweiler, J. M.; Hoffman, R. V. J. Org. Chem. 1986, 51, 5013.

11. Bos, M.; Dahmen, E. A. M. F. Anal. Chim. Acta 1971, 57, 361.

12. Acetal $\mathbf{2 4}$ was not detected in DNBSA-catalyzed reduction of ketones with anti-1,3-diols 15 . On the other hand, syn-1,3diol 11 gave the corresponding acetal 16 which has two methyl groups both in equatorial positions (Table 4, Entry 4).

13. (a) Ishihara, K.; Hanaki, N.; Yamamoto, H. J. Am. Chem. Soc 1991, 113, 7074; (b) Ishihara, K.; Hanaki, N.; Yamamoto, H. Synlett 1993, 127; (c) Ishihara, K.; Hanaki, N.; Yamamoto, H. J. Am. Chem. Soc. 1993, 115, 10695.

14. (a) Shaw, P. E. J. Org. Chem. 1966, 31, 2116; (b) Martin, O. R.; Rao, S. P.; El-Shenawy, H. A.; Kurz, K. G.; Cutler, A. B. J. Org. Chem. 1988, 53, 3287.

15. Djerassi, C. Org. React. 1951, 6, 207.

16. Allylic alcohol formed by reduction of $\mathbf{2 6}$ was not obtained, probably because dehydration of the allylic alcohol took place.

17. Fleming, I.; Barbero, A.; Walter, D. Chem. Rev. 1997, 97, 2063.

18. Huckins, J. R.; Rychnovsky, S. D. J. Org. Chem. 2003, 68, 10135.

19. Buynak, J. D.; Strickland, J. B.; Lamb, G. W.; Khasnis, D.; Modi, S.; Williams, D.; Zhang, H. J. Org. Chem. 1991, 56, 7076 .
20. (a) Buynak, J. D.; Strickland, J. B.; Hurd, T.; Phan, A. J. Chem. Soc., Chem. Commun. 1989, 89; (b) Soderquist, J. A.; Anderson, C. L.; Miranda, E. I.; Rivera, I.; Kabalka, G. W. Tetrahedron Lett. 1990, 31, 4677; (c) Takeda, K.; Ohnishi, Y.; Koizumi, T. Org. Lett. 1999, 1, 237; (d) Arai, N.; Suzuki, K.; Sugizaki, S.; Sorimachi, H.; Ohkuma, T. Angew. Chem., Int. Ed. 2008, 47, 1770.

21. (a) Ricci, A.; Degl'Innocenti, A. Synthesis 1989, 647; (b) Bonini, B. F.; Comes-Franchini, M.; Fochi, M.; Mazzanti, G.; Ricci, A. J. Organomet. Chem. 1998, 567, 181; (c) Cirillo, P. F.; Panek, J. S. Org. Prep. Proced. Int. 1992, $24,553$.

22. Bonini, B. F.; Comes-Franchini, M.; Fochi, M.; Mazzanti, G.; Peri, F.; Ricci, A. J. Chem. Soc., Perkin Trans. 1 1996, 2803.

23. (a) Bock, H.; Alt, H.; Seidl, H. J. Am. Chem. Soc. 1969, 91, 355; (b) Yoshida, J.; Itoh, M.; Matsunaga, S.; Isoe, S. J. Org. Chem. 1992, 57, 4877.

24. Rychnovsky, S. D.; Griesgraber, G.; Zeller, S.; Skalitzky, D. J. J. Org. Chem. 1991, 56, 5161.

25. Guijarro, A.; Yus, M. Tetrahedron 1996, 52, 1797.

26. Todesco, R.; Bockstaele, D. V.; Gelan, J.; Martens, H.; Put, J.; De Schryver, F. C. J. Org. Chem. 1983, 48, 4963.

27. Reich, H. J.; Eisenhart, E. K.; Olson, R. E.; Kelly, M. J. J. Am. Chem. Soc. 1986, 108, 7791.

28. Yamamoto, K.; Hayashi, A.; Suzuki, S.; Tsuji, J. Organometallics 1987, 6, 974.

29. Enda, J.; Kuwajima, I. J. Am. Chem. Soc. 1985, 107, 5495.

30. Clark, C. T.; Milgram, B. C.; Scheidt, K. A. Org. Lett. 2004, 6, 3977.

31. Doussot, P.; Portella, C. J. Org. Chem. 1993, 58, 6675.

32. Cossrow, J.; Rychnovsky, S. D. Org. Lett. 2002, 4, 147.

33. Ohtani, I.; Kusumi, T.; Kashman, Y.; Kakisawa, H. J. Am. Chem. Soc. 1991, 113, 4092

34. Cozzi, P. G.; Kotrusz, P. J. Am. Chem. Soc. 2006, 128, 4940.

35. Eagon, S.; Kim, J.; Yan, K.; Haddenham, D.; Singaram, B. Tetrahedron Lett. 2007, 48, 9025.

36. Yang, W. K.; Cho, B. T. Tetrahedron:Asymmetry 2000, 11, 2947.

37. Shimoda, K.; Kubota, N.; Hamada, H.; Yamane, S. Y.; Hirata, T. Bull. Chem. Soc. Jpn. 2004, 77, 2269.

38. Sokeirik, Y. S.; Mori, H.; Omote, M.; Sato, K.; Tarui, A.; Kumadaki, I.; Ando, A. Org. Lett. 2007, 9, 1927. 